\title{
ACCESS TO MICROFINANCE BANKS CREDIT FACILITY AND POVERTY ALLEVIATION THROUGH IMPROVED INCOME AMONG THE PEOPLE OF CROSS RIVER STATE, NIGERIA
}

\author{
UYANG, FRANCIS ABUL (CORRESPONDING AUTHOR) \\ DEPARTMENT OF SOCIOLOGY, \\ FACULTY OF SOCIAL SCIENCES, UNIVERSITY OF CALABAR \\ CALABAR, CROSS RIVER STATE, NIGERIA \\ Email: francisuyang@yahoo.com \\ ABANBESHIE JEREMIAH A. \\ DEPARTMENT OF CONTINUING EDUCATION AND DEVELOPMENT STUDIES, FACULTY OF \\ EDUCATION, \\ UNIVERSITY OF CALABAR, CALABAR, CROSS RIVER STATE, NIGERIA \\ Email: jerryabambeshie@gmail.com \\ OMONO, CLETUS EKOK \\ DPEARTMENT OF SOCIOLOGY \\ FACULTY OF SOCIAL SCIENCE \\ UNIVERSITY OF CALABAR, CALABAR, CROSS RIVER STATE, NIGERIA \\ Email: omonocletus@unical.edu.ng \\ ABOH, FIDELIS ISOMKWO \\ DEPARTMENT OF SOCIOLOGY, FACULTY OF SOCIAL SCIENCES \\ UNIVERSITY OF CALABAR, CALABAR, CROSS RIVER STATE, NIGERIA \\ Email: abohfide2012@yahoo.com
}

\begin{abstract}
The study examined the relationship between access to microfinance banks facility and poverty alleviation through improved income among the people of Cross River State, Nigeria. One null hypothesis was formulated in study. Using the survey research design, data were collected from 572 randomly selected respondents. The data were statistically analyzed using chi-square test statistic at 0.01 significant level. The result showed that a significant association exists between access to credit facility and poverty alleviation in terms of improved income. The study recommended that microfinance banks should increase the amount of money given as credit to enable customers expands their businesses and investment, and enable them generate more income. It was also recommended that when credit facility(ies) are granted or given to customers, there should be follow-up by microfinance banks to ensure that it is judiciously used.
\end{abstract}

Keywords: Microfinance, microfinance banks, credit facility, poverty alleviation.

DOI: $10.7176 / \mathrm{IKM} / 11-4-08$

Publication date:August $31^{\text {st }} 2021$

\section{INTRODUCTION}

\subsection{Background and statement of problem}

Microfinance is centred on the fact of economic relations, that the poor remain poor, they are deprived of access to life transformation opportunities such as affordable financial services. As development strategy, microfinance confidence is built on ability of the poor to meaningfully improve their conditions of living, if they can access financial support on affordable terms (Eligiamusoe, 2008).

Income is one of the important elements of living standards of the poor people (Mohammed \& Mohammed, 2007; cited in Idowu \& Oyeleye, 2012). Microfinance has positive impact on the economy. After collecting loan, borrowers income and their expenditure on family increase extensively, customers' income level also increased which shows that they are able to cross only the extreme poverty line while still remaining near the poverty line (Ayuu, 2013). Mayoux (1995) cited in Okafor (2014) noted that microfinance does have a positive impact on 
customers or clients in terms of income growth and vulnerability, although, the effects are often small and all clients do not benefit equally. Microfinance programmes in terms of access to credit facility have the potential to alleviate poverty especially in increasing level of income and reducing vulnerability (Ashamu \& Ogundina, 2015).

Yahaya, Osemene and Abdulraheem (2011) cited in Alani and Sani (2014) conducted a study on effectiveness of microfinance in poverty alleviation in Kwara State, Nigeria. Using t-test and analysis of variance (ANOVA), the study revealed that microfinance plays significant role in the economy, as it helps in generating employment opportunities and also providing credit facility such as loan to grow small scale businesses which help in improvement of the income of the poor. According to Akinbo and Oni (2012) cited in Alozie (2017), microfinance banks have been able to alleviate poverty among their clients as credits granted are expanded by the beneficiary(ies) thus improving the level of income and moving them out of poverty line. Anyelwisye (2007) stresses that access to bank credit facility is one of the major constraints hindering the development of small informal business not only in Tanzania but also in other countries. He maintains that commercial banks have traditionally concentrated their lending to larger enterprises which possess collateral and are regarded to be less risky.

Murty, Sailaya and Pemissie (2012) cited in Nwankanma, Nnamdi and Omojefe (2014) examined the long-run impact of microfinance banks credits on Ethiopia's economic growth. They adopted a multivariate Johansen's co-integration approach on time series data over the period 1971. The study concludes that microfinance banks credits influence economic growth from 1972 to 2010/2011, the results of their study provide evidence of a positive and significant long-run relationship between microfinance banks credit and economic growth in Ethiopia through efficient resource allocation and domestic capital accumulation. Through access to microfinance banks credit facility, the poor are able to improve their incomes and ameliorate vulnerability to risk, acquire human capital and physical assets, and escape poverty (Owolabi, 2015). Bateman and Chang (2012) argued that a positive relationship between microfinance banks credit facility and reduction is rather ambiguous. For them, in the absence of productive opportunities, repayment capacity will typically be lost and repayment enforcement, is more likely to impoverish borrowers. Access and use of microfinance credit facility by the poor can decrease or increase poverty dependency on the availability of productive opportunities as well as other factors (Vega, 2003; cited in Owolabi, 2015).

According to Imoisi and Opera (2014), the development of credit facilities to serve the poor has been a very beneficial method of alleviating or reducing poverty. They maintain that the dormant ability of the poverty striken populace for private enterprise would be considerably improved by providing micro credit facilities to allow them to participate in various financial, profitable and money making actions and become more independent; generate employment opportunities, improve family earnings, generate income and create wealth for the economy. Furthermore, Imoisi and Opara (2014) conducted a study on microfinance and its impact on poverty alleviation: case study of some microfinance banks in Edo State, Nigeria. The findings show that access to micro-credit facility and availability has a positive impact on poverty and on living standards of recipients in the study area. The reason for their conclusion is that when people with micro enterprises have access to credit facility, they will be able to expand their businesses, employ more people, improve their standards of living and that of the people they employed. One of the most important roles of access to credit facility is that it enables the poor who normally do not have one of income or livelihood, but resort to a mixture of activities depending on the season, prices, their health and other contingencies to acquire capital for the financing of multiple petty projects (Opera, 2010).

Akosile and Ajayi (2014) conduct a study on the impact of microfinance institutions on poverty reduction in Nigeria. They found that microfinance especially the Microfinance Banks (MFBs) and cooperate investment and credit societies (CICSs) is a major tool in alleviating poverty. The result from the study showed that microfinance banks (MFBs) services have significantly aided poverty alleviation in terms of income generating capacities of MSMEs and expansion in the business of the informal groups. The study also showed that credit facility and other financial services provided by microfinance banks and cooperative investment and credit societies (CICSs) enable the poor and low income group to engage in economic activities that make them self reliance, enhances their household income and help them create wealth which in turn reduce poverty. The study concluded that the poor, low income people and MSMEs use the credit and financial facilities provided by MFIs like MFBs and CICSs in building their business thereby increasing their income and reduce poverty in Nigeria.

Nwigwe, Omonona and Okoruwa (2012) contend that microfinance is advocated as a solution to multiple social problems in Nigeria. According to them, poor people with access to credit can make investment in enterprises 
that could improve their level of income and bring them out of poverty. Kazi and Leonard (2012) admit that there is great evidence that Grameen Bank's poverty alleviation strategy through its credit operations have produced a positive impact on the lives of the poor in terms of higher income level and empowerment of the rural women. Microfinance credit facility is seen as a viable alternative to conventional banking as it plays a vital role in positively affecting the socioeconomic lives of the rural people through income generation (Uyang, Akwaji \& Ezikeudu, 2015). Nkpoyen and Bassey (2012) conclude that access to credit leads to increased income and reduce poverty as well enhanced physical mobility, ownership of productive assets, increased involvement in community decision making and self worth.

In Nigeria, generally and in Cross River State in particular, government for years now, are unable to efficiently aid the poor as demonstrated by several failed poverty alleviation projects. Thus, microfinance banks were created as a means for poverty reduction through the provision to poor population small grants, micro-credits and other microfinance services in order to improve their income and livelihoods in general (Taiwo, 2012; Ashamu \& Ogundina, 2015). The fact is that many poor people in Cross River State, about 41.4 percent, require micro/small financial services such as credit, savings, money transfer etcetera in order to engage actively in the productive activities and improve their standard of living (Inyang, Arikpo \& Ndiyo, 2015).

\section{Objective of the paper}

The paper investigated access to microfinance banks credit facility and poverty alleviation through improved income among the people of Cross River State, Nigeria. Specifically, it

i. Examined the extent to which access to credit facility alleviates poverty in terms of improved income among the people in Cross River State

\section{Research hypothesis}

i. Access to credit facility has no significant association with poverty alleviation in terms of improved income among the people in Cross River State.

\section{Theoretical framework}

\subsection{The vicious cycle theory of poverty}

The vicious cycle theory of poverty states that the poor man is poor because he is poor or a country is underdeveloped because it is underdeveloped (Jhinghan, 2003). The vicious cycle of poverty is a kind of curse which is feared by individuals and countries because it is said that an individual/country is poor because it is poor. The theory states that there are circular relationships known as the vicious cycle of poverty, that tend to perpetuate the low level of development in less developed countries (LDCs). The trajectory is that poverty is caused by low income. Low income engenders low savings and this in turn leads to low investment. The latter provokes the productivity and the cycle continues.

Jhingan (2003) emphasize that the basic vicious cycle stems from the facts that in LDCs total productivity is low due to deficiency of capital, market perfections, economic backwardness and underdevelopment. The vicious cycle operates both on the demand size and supply side. On the demand side of the vicious cycle, the low level of real income leads to a low level of demand, which in turn leads to a low rate of investment and hence back to deficiency of capital, low productivity and low income. The low level of savings leads to low investment and to deficiency of capital. The deficiency of capital in turn leads to low level of productivity and back to a low income.

The possibility of accessing credit facility through microfinance bank can help to meet up with the demands of capital deficiency. The basic assumption of the theory is that poverty is precipitated by low income. Through microfinance banks, people will access credit facility, the propensity to develop saving habit will be enhanced, investment will be promoted and together with entrepreneurship development. All these actions have moderate low levels of savings that leads to low investment that results from deficiency of capital the overall impact is poverty reduction. 


\section{Methods and material}

The research design adopted for the study was survey. A questionnaire was designed based on the variable drawn from the study. Cross River is the study area with a population of 3,866,300 (National Population Census and National Bureau of Statistics Estimation, 2016). Cross River State is grouped into three senatorial districts. They are Northern Senatorial District, Central Senatorial District and Southern Senatorial District with 18 Local Government Areas. The study adopted the multi-stage sampling procedures. The state was stratified along the existing three senatorial districts. These three (3) senatorial districts constituted the three strata of the study. Purposive sampling procedure was used to select one third (1/3rd) of the local government areas per major stratum. The breakdown of the Senatorial Districts indicated that the South has 7 LGAs, the central has 6 LGAs while the North has 5 LGAs. The total number of LGAs in the Senatorial District is 18 . Thus, represented strata 1,2 and 3 respectively. One third of the local government areas translates to 2 local government areas per stratum. This yielded to 6 LGAs. These constituted the 6 minor strata.

Systematic sampling technique was adopted to select the actual respondents of the study. This was used to select between 115 and 97 respondents from village/ward (cluster). It involved the enumeration of households in each village or community or wards or street as usually done during census $(1,2,3,4,5,6,7,8,9,10$ etc.). The researcher used even numbered households in a systematic manner. It amounted to 600 respondents who participated in the study. Since minor stratum A was Calabar Municipality and being the Cross River State headquarters, the number of beneficiaries identified were more. Altogether, 115 respondents were involved in minor stratum. For the rest of the remaining 5 minor strata, 97 respondents were involved. Therefore, a total of 600 respondents (participants) participated in the quantitative study. This sample size was considered appropriate for generalization. Data derived from the administration of the questionnaire were analyzed using simple percentages and chi-square statistical test. The percentages were used to describe the socio-demographic characteristics of respondents in the study, while chi-square statistical test was used to test the hypothesis formulated for the study.

\section{Analysis}

For this study, a total of 600 copies of questionnaire were distributed while 572 were returned. The analysis was therefore based on 572 questionnaire retrieved from the field and at 0.01 significant level. The sociodemographic statistics of respondents was examined first before testing the hypothesis drawn for the study.

Table 1: Distribution of respondents

\begin{tabular}{lcc}
\hline & No of respondent & Per centage of respondent \\
\hline Age bracket & 251 & 43.88 \\
$25-30$ years & 192 & 33.56 \\
$31-35$ years & 76 & 13.28 \\
36 - 40 years & 27 & 4.72 \\
$41-45$ years & 19 & 3.34 \\
$46-50$ years & 7 & 1.22 \\
$50+$ years & & \\
& & \\
Marital status & 312 & 55.22 \\
Single & 224 & 39.65 \\
Married & 21 & 3.72 \\
Divorced & 8 & 1.41 \\
Widowed & & \\
LGA & 95 & 16.61 \\
Akamkpa & 111 & 19.40 \\
Calabar Municipal & 97 & 16.96 \\
Ikom & 91 & 15.91 \\
Obubra & 93 & 16.26 \\
Obudu & 85 & 14.86 \\
Ogoja & & \\
Religion & 481 & 95.06 \\
Christianity & 6 & 1.19 \\
ATR & 19 & 3.75 \\
Islam & &
\end{tabular}




\begin{tabular}{|c|c|c|}
\hline \multicolumn{3}{|l|}{ Occupation } \\
\hline Farming & 211 & 36.89 \\
\hline Fishing & 82 & 14.33 \\
\hline Trading & 120 & 20.98 \\
\hline Civil service & 128 & 22.38 \\
\hline Unemployed & 21 & 3.67 \\
\hline Others & 10 & 1.75 \\
\hline \multicolumn{3}{|l|}{ Education } \\
\hline Primary & 98 & 17.13 \\
\hline Secondary & 136 & 23.78 \\
\hline Tertiary & 309 & 54.02 \\
\hline Informal & 29 & 5.07 \\
\hline \multicolumn{3}{|l|}{ Income } \\
\hline Less than N50,000 & 166 & 29.02 \\
\hline $\mathrm{N} 51,000-\mathrm{N} 100,000$ & 231 & 40.39 \\
\hline $\mathrm{N} 101,000-\mathrm{N} 200,000$ & 98 & 17.13 \\
\hline $\mathrm{N} 201,000-\mathrm{N} 300,000$ & 52 & 9.09 \\
\hline Above N300,000 & 25 & 4.37 \\
\hline \multicolumn{3}{|l|}{ Sources of capital } \\
\hline Credit facility from & 357 & 62.41 \\
\hline \multicolumn{3}{|l|}{ Microfinance } \\
\hline $\begin{array}{l}\text { Credit facility from Coop. } \\
\text { society }\end{array}$ & 198 & 34.61 \\
\hline Payment transfer & 17 & 2.97 \\
\hline \multicolumn{3}{|l|}{ Sources of income per month } \\
\hline Profit from trading & 120 & 20.98 \\
\hline Profit from fishing & 81 & 14.16 \\
\hline Profit from enterprises & 41 & 7.17 \\
\hline Salary & 128 & 22.38 \\
\hline Profit from agriculture & 192 & 33.56 \\
\hline Other investment & 10 & 1.75 \\
\hline \multicolumn{3}{|l|}{ No of children } \\
\hline None & 167 & 29.20 \\
\hline $1-2$ & 232 & 40.56 \\
\hline $3-5$ & 143 & 25.00 \\
\hline $6+$ & 30 & 5.24 \\
\hline
\end{tabular}

Source: Fieldwork, 2019

Table 1 indicates the socio demographic data of respondents. The distribution indicated that 251 respondents representing 43.88 per cent of the total respondents were between the ages of 25 and 30 years, 192 respondents representing 33.56 per cent were between the ages of 31 and 35 years, 76 respondents representing 13.28 per cent were between the ages of 36 and 40 years, 27 respondents were aged between 41 and 45 years while 19 respondents representing 3.34 per cent were between the age bracket of 46 and 50 and seven respondents representing 1.22 per cent were above 50 years. Among the respondents, 312 representing 55.22 per cent were single, 224 respondents representing 39.65 per cent were married, 21 respondents representing 3.72 per cent were divorced and eight respondents were widowed. Also, the distribution showed that 95 respondents representing 16.61 per cent were resident in Akamkpa, 111 respondents representing 19.40 per cent were resident in Calabar Municipal, 97 respondents representing 16.96 per cent were residing at Ikom, 91 respondents were in Obubra, 93 respondents in Obudu and 85 respondents representing 14.86 per cent were resident in Ogoja Local Government Area. With regard to religion, 481 respondents representing 95.05 per cent were Christians, six and 19 respondents respectively belonged to African traditional religion and Islam.

Also, the distribution showed that 211 respondents representing 36.89 per cent were farmers, 82 respondents representing 24.33 per cent were fishermen/women, 120 respondents representing 20.98 per cent were traders, 128 respondents representing 22.38 per cent were civil servants, 21 respondents were unemployed and other categories not listed were 10 respondents. The distribution further showed that 98 respondents out of 572 had primary education as their highest educational qualification, 136 respondents representing 23.78 per cent had 
secondary education, 309 respondents representing 54.02 had tertiary education and 29 respondents had no formal education. The monthly income levels of the respondents were: 166 respondents representing 29.02 per cent earned below N50,000, 231 respondents representing 40.39 per cent earned between N51,000 and N100,000, 98 respondents representing 17.13 per cent had their monthly earnings between N101,000 and N200,000 while 52 respondents earned between N201,000 and N300,000 and 25 respondents representing 4.37 per cent earned above N300,000 monthly.

For sources of capital, the Table indicated that 357 respondents representing 62.41 per cent stressed that their source of capital was credit facility from microfinance, 198 respondents representing 34.61 indicated credit facility from cooperative society while the remaining 17 respondents indicated payment transfer as their source of capital. With regard to sources of income per month, the distribution showed that 120 respondents representing 20.98 indicated profit from trading, 81 respondents representing 14.16 per cent indicated profit from fishing, 41 respondents representing 7.17 indicated profit from enterprises, 128 respondents indicated that their source of monthly income was salary, 192 respondents representing 33.56 per cent indicated profit from agricultural activities and 10 respondents indicated other investments as sources of their monthly income. The respondents also indicated the number of children they have; 167 respondents representing 29.20 per cent had no children, 232 respondents representing 40.56 per cent had children between one and two, 143 respondents representing 25 per cent had three to five children while 30 respondents had six and above children representing 5.24 percent.

Table 2: Descriptive Statistics

\begin{tabular}{|c|c|c|c|c|c|c|c|c|}
\hline & \multirow{2}{*}{$\begin{array}{c}\mathrm{N} \\
\text { Statisti } \\
\mathrm{c}\end{array}$} & \multirow{2}{*}{$\begin{array}{c}\text { Mean } \\
\text { Statisti } \\
\text { c }\end{array}$} & \multirow{2}{*}{$\begin{array}{l}\text { Std. Dev } \\
\text { Statistic }\end{array}$} & \multirow{2}{*}{$\begin{array}{l}\text { Variance } \\
\text { Statistic }\end{array}$} & \multicolumn{2}{|c|}{ Skewness } & \multicolumn{2}{|c|}{ Kurtosis } \\
\hline & & & & & $\begin{array}{l}\text { Statisti } \\
\mathrm{c}\end{array}$ & $\begin{array}{l}\text { Std. } \\
\text { Error }\end{array}$ & $\begin{array}{l}\text { Statisti } \\
\mathrm{c}\end{array}$ & $\begin{array}{l}\text { Std. } \\
\text { Error }\end{array}$ \\
\hline \multicolumn{9}{|c|}{ Access to credit facility and poverty alleviation } \\
\hline Ease to obtain loan & 572 & 1.41 & .493 & .243 & .356 & .102 & -1.880 & .204 \\
\hline Small business expansion & 572 & 1.48 & .500 & .250 & .084 & .102 & -2.000 & .204 \\
\hline Potential to improve income & 572 & 1.72 & .451 & .203 & -.965 & .102 & -1.073 & .204 \\
\hline Preference of microfinance services & 572 & 1.63 & .483 & .233 & -.545 & .102 & -1.709 & .204 \\
\hline Benefits of access to credit to the poor & 572 & 1.53 & .499 & .249 & -.141 & .102 & -1.987 & .204 \\
\hline Improve habit for private enterprise & 572 & 1.50 & .500 & .250 & -.007 & .102 & -2.007 & .204 \\
\hline $\begin{array}{l}\text { Benefit of microfinance services to } \\
\text { family \& community }\end{array}$ & 572 & 1.56 & .496 & .246 & -.262 & .102 & -1.938 & .204 \\
\hline
\end{tabular}

Sources: SPSS Output

Table 2 showed the general descriptive statistics of the survey. The distribution described the statistical structure of the data collated for the survey. Generally $\mathrm{N}$ represented the number of respondent that reacted to the items, the mean is the average response of the respondents, the standard deviation indicated the deviation of the responses from the mean while skweness and kurtosis indicated the shape of the data in term of peak. The Table indicated that the items were all responded to, hence $\mathrm{N}=572$. For access to credit facility and poverty alleviation the distribution showed (ease to obtain loan) mean $=1.41$, standard deviation $=0.493$, variance $=0.243$ while the statistics for skewness and kurtosis were 0.356 and -1.880 respectively. For use of facility to expand small business the statistics were $\mathrm{N}=572$, mean $=1.48$, standard deviation 0.500 , variance $=0.250$, skewness $=0.084$ and kurtosis $=-2.000$. For potential of microfinance programme to improve income of the poor, the statistics revealed $\mathrm{N}=572$, mean $=1.72$, standard deviation 0.451 , variance $=0.203$, skewness $=-0.965$ and kurtosis $=$ 1.073. For preference of microfinance services to commercial banks, the responses showed $\mathrm{N}=572$, mean $=$ 1.63, standard deviation 0.483 , variance $=0.233$, skewness $=-0.545$ and kurtosis $=-1.709$. On whether access to credit has benefited the poor, the responses indicated $\mathrm{N}=572$, mean $=1.53$, standard deviation 0.499 , variance $=$ 0.249 , skewness $=-0.141$ and kurtosis $=-1.987$. The responses to whether access to credit facilities has shape peoples habit to private enterprise showed $\mathrm{N}=572$, mean $=1.50$, standard deviation 0.500 , variance $=0.250$, skewness $=-0.007$ and kurtosis $=-2.007$. The responses to benefits of microfinance services to family and community revealed $\mathrm{N}=572$, mean $=1.56$, standard deviation 0.496 , variance $=0.246$, skewness $=-0.262$ and kurtosis $=-1.938$.

\subsection{Hypothesis one}

Access to credit facility has no significant association with poverty alleviation in terms of improved income level among the people in Cross River State.

Test statistic: Chi-square analysis 
Table 3: Chi square analysis for test of association between access to credit facilities and level of income

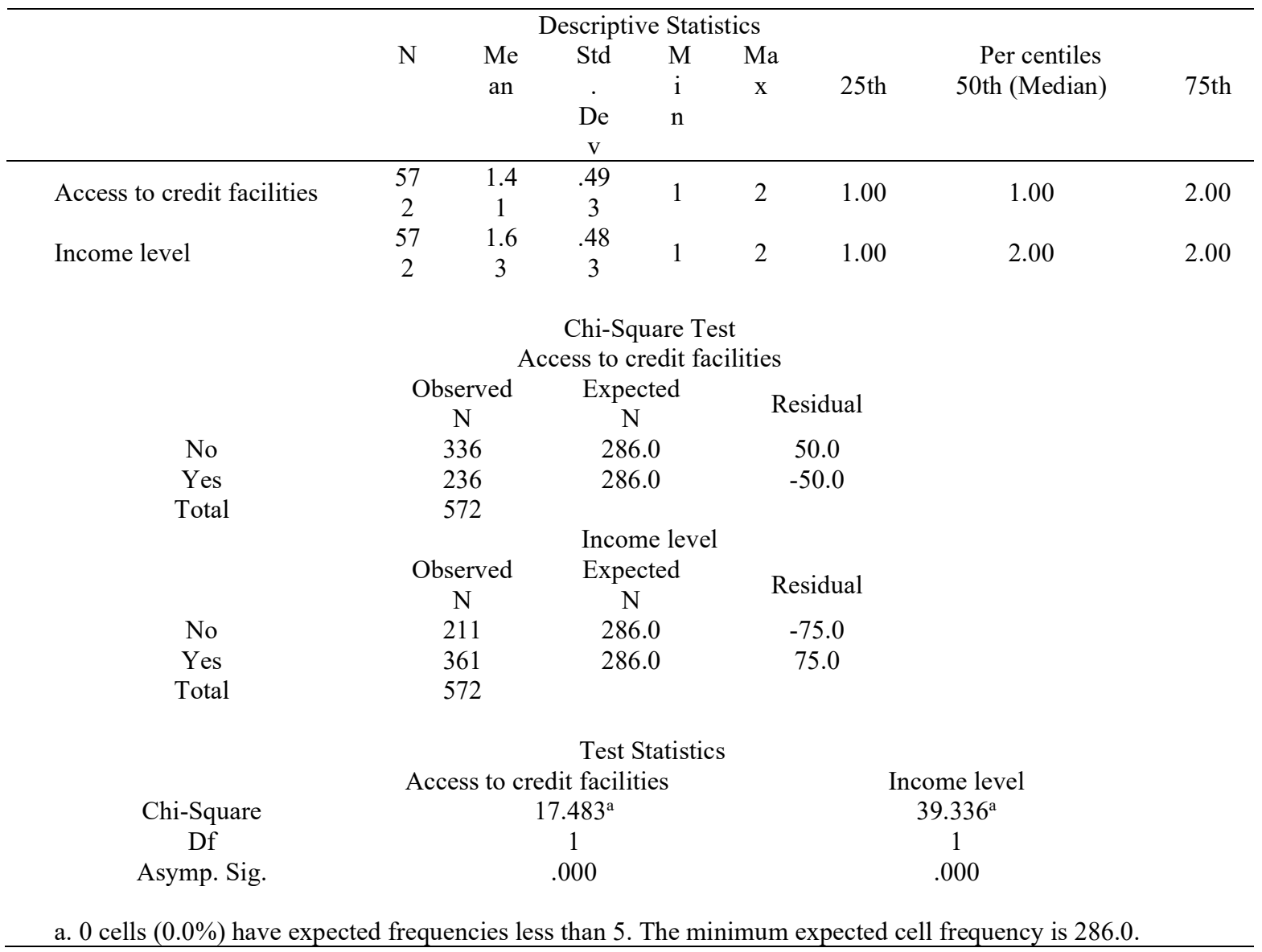
Source: SPSS Output

Table 3 presented Chi square analysis for test of association between access to credit facilities and poverty alleviation in terms of improved income among the people in Cross River State. The results of the test showed both descriptive statistic for the association between access to credit facilities and level of income of the people; the mean response for access to credit facility was 1.41 out of available 2 points while the mean response for level of income was 1,63. The standard deviation varied slightly with 0.10 , which did not revealed any significant deviation in their mean responses. The quartile range between the variables was also infinitesimal therefore the observed and expected chi square values yielded 17.483 and 39.336 for access to credit facilities and level of income respectively, at 0.01 significant level. Since the test statistic for both variables were significant, it was concluded that access to credit facilities has a significant association with poverty alleviation in terms of improved income among the people in Cross River State. This was confirmed by comparing the values of the test statistics access to credit facilities (17.483) and level of income (39.336) to the critical table value of 10.8 at 0.01 and a degree of freedom. The critical table value was much less that the values of the calculated chi square statistics.

\section{Result and Discussion}

The analysis showed that a significant association exist between access to credit facility and poverty alleviation in terms of improved income. The findings is in support of Yahaya, Osemene and Abdulraheem (20011) cited in Alani and Sani (2014), they conducted a study on effectiveness of microfinance on poverty alleviation in Kwara state, Nigeria, the study revealed that microfinance played significant role in the economy, as it helped generating employment opportunities and provide credit facility such as loan to grow small scale businesses which helped in improvement of the income of the poor. The findings also agree with Akinlo and Oni (2012) 
cited in Alozie (2017), they observed microfinance banks have been able to alleviate poverty among their clients as credit granted were expanded by the beneficiary(ies) which improve the level of income and move them out of poverty.

The findings are in line with Murty, Sailaja and Permissre (2012) cited in Nwankanma, Ikechukwu and Omojefe (2014), they examined the long-run impact of microfinance banks credits on Ethiopia's economic growth, the results of their study provide evidence of a positive and significant long-run relationship between microfinance banks and economic growth. The study concludes that microfinance bank credits influence economic growth in Ethiopia through efficient resource allocation and domestic capital accumulation. The findings are congruent with Owolabi (2015), according him, through access to microfinance banks credit facility, the poor are able to improve their incomes and ameliorate vulnerability to risk, acquire human capital and physical assets, and escape poverty. The findings confirm Imoisi and Opera (2014) contention that the development of credit facilities to serve the poor has been a very beneficial method of alleviating or reducing poverty. They maintain that the dormant ability of the poverty stricken populace for private enterprise would be considerably improved by providing micro credit facilities to allow them to participate in various financial, profitable and money making actions and become more independent; add to employment opening, improved family earnings, generate income and create wealth for the economy.

The findings are consistent with Akosile and Ajayi (2014) who conducted a study on the impact of microfinance institutions on poverty reduction in Nigeria. They found that microfinance especially the Microfinance Banks (MFBs) services significantly aided poverty alleviation in terms of income generating capacities of MSMEs and expansion in the business of the informal groups. The study showed that credit facility and other financial services provided by microfinance banks and cooperative investment and credit societies (CICSs) enable the poor and low income group to engage in economic activities that makes self reliance, enhances their household income and help them create wealth which in turn reduce poverty. The study concluded that the poor, low income people and MSMEs use the credit and financial facilities provided by MFIs like MFBs and CICSs in building their business thereby increasing their income and reduce poverty in Nigeria. The findings are in agreement with Mwigwe, Omonona and Okoruwa (2012), they contended that microfinance is advocated as a solution to multiple social problems in Nigeria. According to them, poor people with access to credit can make investment in enterprises that could improved their level of income and bring them out of poverty.

\section{Conclusion}

Poverty alleviation has been an impending challenges to development strategies. Among the identified challenges that the very poor face includes not having access to funds within the formal sector making them not taking advantage of opportunities which abound in the economy towards increasing the output and bettering their livelihood, therefore living above poverty. Poverty alleviation measures have suffered from inability to target the poor especially in rural areas. Thus, over the years, the issue of poverty has continued to assume a global status both in dimension and efforts to reduce it. Other poverty alleviation efforts have not yielded significant improvement in the socioeconomic lives of people, a focus on microfinance banks credit facility may help reduce poverty.

\section{Recommendations}

1) Microfinance banks should increase the amount of money given as credit to enable customers expand their businesses and investments to enable them generate more income.

2) When credit facility(ies) are granted or given to customers, there should be follow up by microfinance banks to ensure that it is judiciously used.

\section{REFERENCES}

Akosile, A. I. \&Ajayi, O. A. (2014).The impact of microfinance institutions on poverty reduction in Nigeria.European Journal of Business and Management, 6(35), 1-7.

Alani, G. O. \& Sani, J. (2014).Effects of microfinance banks on the rural dwellers in Kogi State, Nigeria. International Journal of Public Administration and Management Research, 2(2), 66-79. 
Alozie, N. (2017). Accessing the influence of microfinance on improving poverty status of households in Abia State.International Journal of Advance Studies in Economics and Public Sector Management, 5(1), 105-113.

Anyelwisye, B. (2007). Impact of microfinance institutions on poverty reduction among smallholder farmers: Case of selected SACCOS in Dodoma Urban and Kongwa Districts. Published M.Sc. thesis submitted to Department of Agricultural Economics, Sokoine University of Agriculture, Morogoro, Tanzania.

Ashamu, S. O. \& Ogundina, J.A (2015). An assessment of impact of microfinance banks on poverty alleviation in Nigeria: An Empirical investigation. Journal of Policy and Development Studies, 9(2), 83-89.

Ayuub, S. (2013). Impact of microfinance on poverty alleviation: A case study of NRSP in Bahawalpur of Pakistan. International Journal of Academic Research in Accounting, Finance and Management Sciences, 3(1), 119-135.

Bateman, M. \& Chang, H. J. (2012). Microfinance and the illusion of development: From Hubris to Nemises in thirty years. World Economic Review, 1(1), 13-36.

Ehigiamusoe, G. (2008). The role of microfinance institutions in the economic development of Nigeria. Central Bank of Nigeria Bullion, 32(1), 13-36.

Idowu, A. \& Oyeleye, O. A. (2012). Impact of microfinance banks on poverty alleviation in selected local government areas of Oyo State, Nigeria. European Journal of Business and Management, 4(21), 125-137.

Imoisi, A. I. \& Opara, G. I. (2014). Microfinance and its impact on poverty alleviation: A case study of some microfinance banks in Edo State, Nigeria. American Journal of Humanities and Social Sciences, 2(1), $27-41$.

Inyang, E., Arikpo, D. \& Ndiyo, N. (2015). Unemployment and poverty in Nigeria: The Cross River State situation. Multi-Disciplinary Journal of Research and Development Perspectives, 4(1), 64-73.

Jhingan, M. L. (2003). Economics of development and planning. India: Virinda publication.

Kazi, M. H. \& Lenonard, J. E. (2012). Microfinance, poverty and youth unemployment of Nigeria: A review. Global Journal of Human Social Science, 12(13), 45-59.

Nigeria Population (2019).Nigeria Population 2019.Retrieved $\quad$ May 10, 2021 from http://www.worldo_meters.info.nig.

Nkpoyen, F. \& Bassey, G. E. (2012).Micro-lending as an empowerment strategy for poverty alleviation among women in Yala Local Government Area of Cross River State, Nigeria.International Journal of Business and Social Science, 3(18), 233-241.

Nwakanma, P. C., Nnamdi, I. S. \& Omojefe, G. O. (2014). From rural to microfinance banking; Contributions of microcredits to Nigeria's economic growth - An ARDL Approach. International Journal of Financial Research, $5(3), 73-85$.

Nwigwe, C. A., Omonona, B. T. \& Okoruwa, V. O. (2012). Microfinance and poverty reduction in Nigeria: A critical assessment. Australia Journal of Business and Management Research, 2(4), 33-40.

Okafor, I. G. (2014). Impact of microfinance banks activities on poverty alleviation in Nigeria: 1993 -2012. Published Ph.D thesis submitted to Department of Banking and Finance, Faculty of Business Administration, University of Nigeria, Enugu campus, Enugu State.

Okpara, G. C. (2010). Microfinance banks and poverty alleviation in Nigeria.journal of Sustainable Development in Africa, 12(6), 177-191.

Owolabi, O. E. (2015). Microfinance and poverty reduction in Nigeria: A case study of LAPO microfinance bank. Published Ph.D thesis submitted to the University of Leeds, Leeds University business school. 
Taiwo, J. N. (2012). The impact of microfinance on welfare and poverty alleviation in Southwest Nigeria. Published Ph.D thesis submitted to Department of Banking and finance, college of Development studies, Covenant University, Ota.

Uyang, F. A., Akwaji, N. F. \& Ezikeudu, C. C. (2015).Women association's financial intervention and socioeconomic wellbeing in Akpabuyo Local Government Area, Cross River State, Nigeria.International Journal of Research in Humanities and Social Sciences, 2(8), 43-50. 